\title{
Prediction of dissolved inorganic nitrogen (DIN) concentrations in deep, seasonally stratified lakes based on rates of DIN input and $\mathbf{N}$ removal processes
}

\author{
P. Höhener ${ }^{1, *}$ and R. Gächter ${ }^{2}$ \\ ${ }^{1}$ Institute for Terrestrial Ecology, Swiss Federal Institute of Technology (ETHZ), Grabenstr. 3, \\ CH-8952 Schlieren, Switzerland \\ 2 Institute for Aquatic Sciences and Water Pollution Control, c/o EAWAG, Swiss Federal Institute \\ of Technology (ETHZ), CH-6047 Kastanienbaum, Switzerland \\ * to whom correspondence should be sent
}

Key words: seasonally stratified lakes, dissolved inorganic nitrogen, models, mass balances, sedimentation, gaseous $\mathrm{N}$ loss, denitrification.

\begin{abstract}
Mean dissolved inorganic nitrogen concentrations ([DIN]) in deep, seasonally stratified lakes with comparable DIN inputs can differ by up to a factor of 3 depending on hydraulic and morphometric properties and/or different trophic states of the lakes. In such lakes, net $\mathrm{N}$ sedimentation rates were estimated with two independent methods (sediment core analysis and input-output mass balances). They were higher in eutrophic lakes (Mean: 5.1 ; SD: $\pm 1.6 \mathrm{~g} \mathrm{~m}^{-2} \mathrm{yr}^{-1} ; \mathrm{n}=13$ ) than in oligotrophic lakes $\left(1.6 \pm 1.0 \mathrm{~g} \mathrm{~m}^{-2} \mathrm{yr}^{-1} ; \mathrm{n}=3\right)$, but independent of [DIN]. Gaseous $\mathrm{N}$ loss rates to the atmosphere, as calculated from combined $\mathrm{N}$ - and P-mass balances from selected lakes, ranged from 0.9 to $37.4 \mathrm{~g} \mathrm{~m}^{-2} \mathrm{yr}^{-1}(\mathrm{n}=10)$ and were positively correlated with [DIN]. Reduction of $\mathrm{NO}_{3}^{-}$to $\mathrm{N}_{2}$ is assumed to be the main cause for gaseous $\mathrm{N}$ losses. A simple one-box mass balance model for [DIN], based on DIN input and rates and kinetics of $\mathrm{N}$ removal processes (net sedimentation and gaseous $\mathrm{N}$ loss) is proposed, and validated with a data base on [DIN] and DIN input in 19 deep, seasonally stratified lakes of central Europe. The model illustrated that the amount of water loading per unit surface area of a lake (called water discharge height $q$ ) is the critical parameter determining mean lake [DIN] relative to mean input [DIN]. Lakes with a $\mathrm{q}>50 \mathrm{~m} \mathrm{yr}^{-1}$ have average [DIN] similar to the [DIN] of the inflows regardless of their trophic states, because input and outflow exceed lake-internal $\mathrm{N}$ removal processes. A high primary production favors DIN removal in lakes with $\mathrm{q}<50 \mathrm{~m} \mathrm{yr}^{-1}$. It is concluded that measures to decrease primary production, e.g. by means of $P$ removal programs, lead to an increase of [DIN] in lakes.
\end{abstract}

\section{Introduction}

The increasing anthropogenic input of dissolved inorganic nitrogen (DIN $=\mathrm{NO}_{3}^{-}+\mathrm{NO}_{2}^{-}+\mathrm{NH}_{4}^{+}$) into aquatic ecosystems has lead to a number of ecological problems including drinking water quality (mainly by $\mathrm{NO}_{3}^{-}$, Leu et al., 1986), fish 
toxicity (by $\mathrm{NH}_{3}$ and $\mathrm{NO}_{2}^{-}$; Müller, 1990), acidification (through oxidation of $\mathrm{NH}_{4}^{+}$, Schuurkes and Mosello, 1988), and the eutrophication of coastal marine ecosystems (Ryther and Dunstan, 1971; Gerlach, 1989; Enoksson et al., 1990). However, increased levels of dissolved inorganic nitrogen concentrations ([DIN]) historically caused little concern in lakes because 1) DIN removal reactions in lakes reduce [DIN] to levels considerably lower than [DIN] in rivers, streams and groundwaters, and 2) DIN is generally not the limiting factor for algal growth in lakes (Gächter, 1968; Stadelmann, 1971).

Nevertheless, [DIN] are still increasing in most of the lakes of central Europe (e.g. Zobrist et al., 1990), mainly due to $\mathrm{N}$ release from farmland (Höhener, 1990) but also due to atmospheric or waste water inputs (Schuurkes and Mosello, 1988). Mean DIN inflow concentrations in lakes $\left([\mathrm{DIN}]_{\text {in }}\right.$ ) with intensive agricultural activity in the catchment areas (e.g. Baldeggersee, Schlatter et al., 1988; Sempachersee, Höhener, 1990) are not far below WHO drinking water standards for $\mathrm{NO}_{3}^{-}$ $\left(50 \mathrm{ppm}=11.3 \mathrm{~g} \mathrm{~N} \mathrm{~m}^{-3}\right)$. However, [DIN] of the receiving lakes are lower $(0.8-$ $2.3 \mathrm{~g} \mathrm{~N} \mathrm{~m}^{-3}$ ), but clearly tend to increase (Zobrist et al., 1990). Therefore, the questions arise: How does [DIN] in lakes depend on DIN input? Will [DIN] eventually reach dangerous concentrations if the input concentrations increase further?

Among lakes with comparable DIN inputs, [DIN] vary up to a factor of 3 indicating considerable differences in removal rates. In lakes two possible $\mathrm{N}$ removal mechanisms are involved: burial and gaseous $\mathrm{N}$ loss. DIN can be taken up by algae and subsequently be buried in the sediments as organic $\mathrm{N}$ or $\mathrm{NH}_{4}^{+}$.

Alternatively, DIN can be transformed to gaseous end products $\left(\mathrm{N}_{2}, \mathrm{~N}_{2} \mathrm{O}, \mathrm{NO}\right.$, $\mathrm{NH}_{3}$ ) by microbial processes (nitrification and denitrification) or by chemical dissociation $\left(\mathrm{NH}_{3}\right)$. Burial and gaseous $\mathrm{N}$ loss are both controlled by physical, chemical and microbiological processes and depend in a complex way on lake trophic state, morphology, hydrology and nitrogen input.

A great number of studies has been carried out to quantify gaseous $\mathrm{N}$ loss and/or net $\mathrm{N}$ sedimentation rates in lakes (for reviews see Knowles, 1982; Seitzinger, 1988). However, the majority of the investigated lakes are shallow, non-stratifying lakes which can not be compared to deep lakes because of fundamental differences concerning sedimentation and resuspension. In seasonally stratified, northtemperate lakes, only limited data on rates of $\mathrm{N}$ removal processes are available (Krummenacher, 1976; Höhener, 1990). Therefore, additional experimental data on $\mathrm{N}$ burial in the sediments of 3 Swiss lakes has been included in this paper. In addition, calculations from combined N/P mass balances provided data on both $\mathrm{N}$ sedimentation rates and gaseous $\mathrm{N}$ loss rates in a number of other deep lakes. Based on the rates and kinetics of these $\mathrm{N}$ removal processes, a one-box model is proposed predicting [DIN] in seasonally stratified lakes with known DIN input. A review of the literature on DIN input and [DIN] in 19 deep European lakes provided the appropriate data base to verify and generalize the principles and rates. To our knowledge, such a model, although somewhat different, has so far only be proposed and verified for shallow Danish lakes (Jensen et al., 1991). 


\section{Methods}

\subsection{Mean [DIN] and DIN input}

Data on [DIN] and DIN input for 19 deep, seasonally stratified, holomictic lakes in central Europe were taken from literature. Unless stated otherwise, [DIN] was calculated as the sum of $\left[\mathrm{NO}_{3}^{-}\right]+\left[\mathrm{NO}_{2}^{-}\right]+\left[\mathrm{NH}_{4}^{+}\right]$. The inlake $[\mathrm{DIN}]$ was calculated according to Bührer (1979) as a volume- and time-integrated mean [DIN]. In cases where only few data were available, [DIN] was calculated as the volume-integrated mean [DIN] at the end of the winter overturn.

In all publications from where DIN input data were taken, input was measured by simultaneous measurement of discharge and nutrient concentrations in at least $50 \%$ of the watershed area of the lakes. Inputs from the remaining area were estimated by extrapolation. Direct atmospheric inputs to the lake surface through wet deposition of DIN were usually included using data on mean [DIN] in precipitation. Dry DIN deposition and atmospheric input through $\mathrm{N}_{2}$-fixation were not included. [DIN] in was calculated by dividing the total DIN inputs by the water volumes added to the lakes. Flushing rate was given as the long term average water discharge in the lake outlet divided by the lake volume. Mean depth was calculated by dividing lake volume by surface area.

\subsection{Sediment core analyses}

Sediment cores ( $11 \mathrm{~cm}$ diameter) were sampled at the deepest locations of Sempachersee, Greifensee und Zürichsee, and sliced into subsamples. After oven drying $\left(90^{\circ} \mathrm{C}\right)$ and homogenization, total nitrogen was analyzed using a Carlo Erba CNS analyzer. The sediment cores were dated using varve counting methods (Losher and Kelts, 1989; Höhener, 1990; Wan et al., 1987). Results obtained by this technique agreed well with these obtained with radioisotope dating techniques applied to cores sampled at the same sites (Wan et al., 1987; Schuler et al., 1991; Wieland et al., 1993). In sediment cores, total $[\mathrm{N}]$ decrease with depth indicating that the sediments lost part of the $\mathrm{N}$ during diagenesis. Thus, only sediment layers where the majority of releasable $\mathrm{N}$ has already diffused back to the sediment surface, were used to assess net $\mathrm{N}$ sedimentation rates (burial rates). Concentration profiles of $\mathrm{NH}_{4}^{+}$and dissolved organic $\mathrm{N}$ in the interstitial waters of the sediment cores from Sempachersee (Höhener, 1990) indicate that the diffusive loss of dissolved $\mathrm{N}$ from sediment layers below $5 \mathrm{~cm}$ depth is negligible. Net $\mathrm{N}$ sedimentation or burial rates can thus be estimated by multiplying the total $\mathrm{N}$ concentration ( $\mathrm{mg} \mathrm{g}^{-1}$ dry weight) of a layer below $5 \mathrm{~cm}$ sediment depth by the sedimentation rate ( $\mathrm{g}$ dry weight $\mathrm{m}^{-2} \mathrm{yr}^{-1}$ ) determined at identical locations. The sediment depth of $5 \mathrm{~cm}$ has been chosen in all 3 lakes as a minimum depth for net $\mathrm{N}$ sedimentation estimations. 


\subsection{Calculation of net $N$ sedimentation rates and gaseous $N$ loss rates} from $N$ - and P-mass balances

Net $\mathrm{N}$ sedimentation rates and gaseous $\mathrm{N}$ loss rates were calculated from $\mathrm{N}$ - and $\mathrm{P}$ mass balances using the method outlined in Vollenweider (1968). Briefly, the net retention rates of $\mathrm{N}$ and $\mathrm{P}$ in lakes were calculated by subtracting the mean output in the lake outlet from mean inputs and the mean change in nutrients of the water body. Unless stated otherwise, input and output data included dissolved as well as particulate forms of nutrients. The calculated $P$ retention rate is identical with the net $\mathrm{P}$ sedimentation (burial) rate, whereas the $\mathrm{N}$ retention is the sum of the net $\mathrm{N}$ sedimentation rate and the gaseous $\mathrm{N}$ loss rate. The net $\mathrm{N}$ sedimentation rate was calculated by multiplying the net $\mathrm{P}$ sedimentation rate by the $\mathrm{N}: \mathrm{P}$ ratio of permanently buried sediment material. N:P ratios in sediments were estimated as arithmetic means of $\mathrm{N}: \mathrm{P}$ data from sediment samples below $2 \mathrm{~cm}$ sediment depth. Sediment samples between the 0 to $2 \mathrm{~cm}$ sediment horizon were omitted because they are usually enriched in P accumulated in bacterial biomass or bound to iron(III) minerals (Gächter et al., 1988). Data from Sempachersee sediments (Gächter et al., 1989) show that $N: P$ ratios in sediment depths $>2 \mathrm{~cm}$ are fairly constant and may be referred to as the N:P ratio of permanently buried sediment material. Finally, the gaseous $\mathrm{N}$ loss rate is obtained as the difference between net $\mathrm{N}$ retention rate minus net $\mathrm{N}$ sedimentation rate.

\section{Results}

\subsection{Literature data on $[D I N]$ and DIN input in deep European lakes}

Data on [DIN] and DIN input for 19 deep, seasonally stratified, holomictic lakes in central Europe are listed in Table 1. The lakes are situated in Austria, Germany, Italy and Switzerland. Original lake names are given instead of translations.

Mean [DIN] in ranged from 0.2 to $6.7 \mathrm{~g} \mathrm{~m}^{-3}$ (Table 1), whereas mean [DIN] in the lakes ranged from 0.25 to $2.3 \mathrm{~g} \mathrm{~m}^{-3}$ and were generally lower than the [DIN] $]_{\text {in }}$. However, high $[D I N]_{\text {in }}$ were not always correlated with high inlake [DIN]. In all lakes, $\mathrm{NO}_{3}^{-}$was the dominant inorganic $\mathrm{N}$ species. High ammonium levels observed in anoxic hypolimnia at the end of the summer stagnation accounted at the maximum for $46 \%$ of [DIN] in Baldeggersee (Stadelmann et al., 1984).

\subsection{Net $N$ sedimentation rates estimated from $N$ profiles in dated sediment cores}

In 3 lakes from which sediment data are available (Fig. $1 \mathrm{a}-\mathrm{c}$ ), the total $\mathrm{N}$ concentrations in the sediments ranged from 1.5 to $9.6 \mathrm{mg} \mathrm{g}^{-1}$ dry weight and decreased with increasing sediment depth. In Zürichsee, sediment from two turbidity currents, dated to 1979 and 1918 (Losher and Kelts, 1989), had to be excluded from our considerations. The estimated net $\mathrm{N}$ sedimentation rates ranged from 2.4 to $5.0 \mathrm{~g} \mathrm{~m}^{-2} \mathrm{yr}^{-1}$ (Table 2) with the lowest value observed in the oligotrophic 


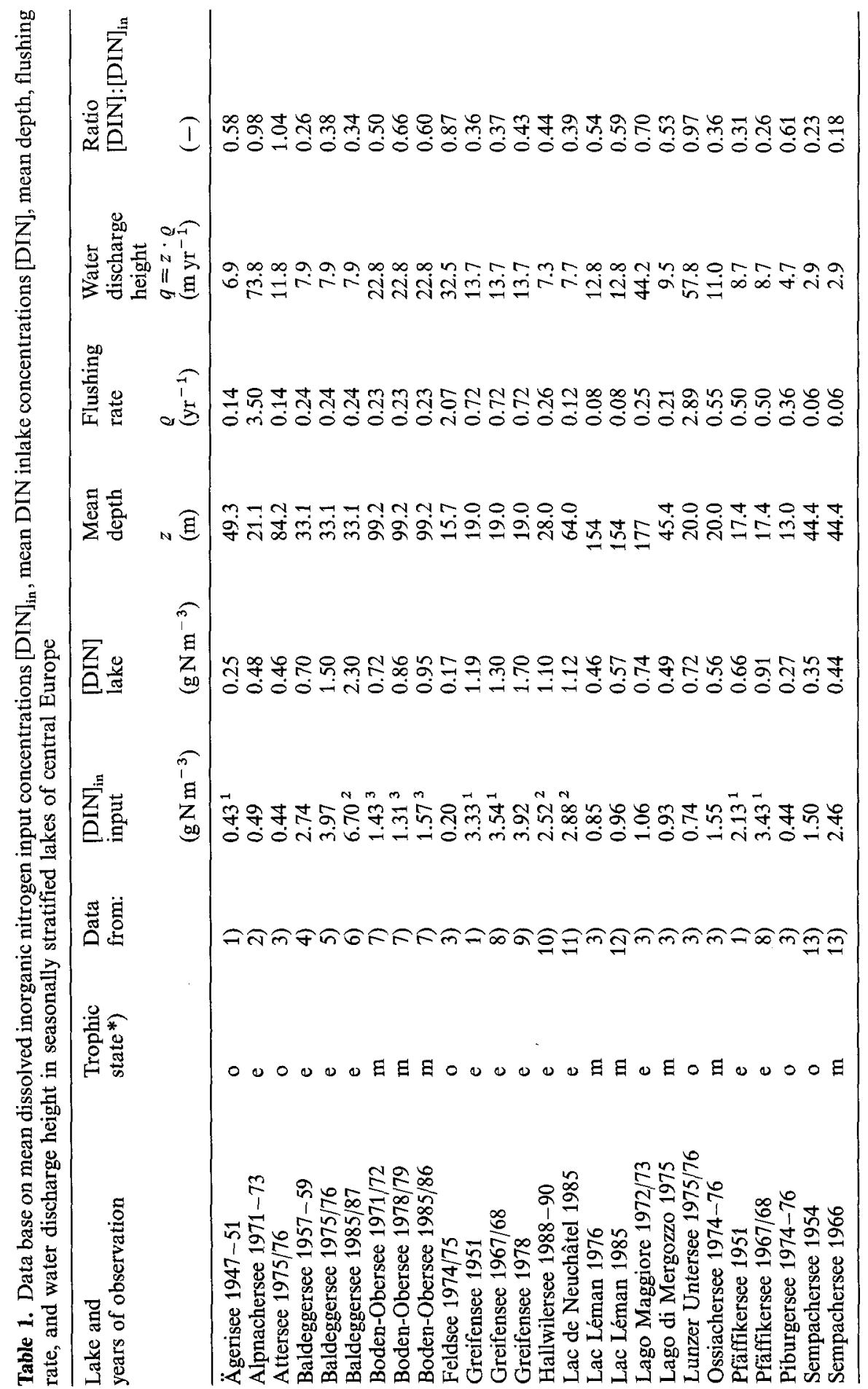




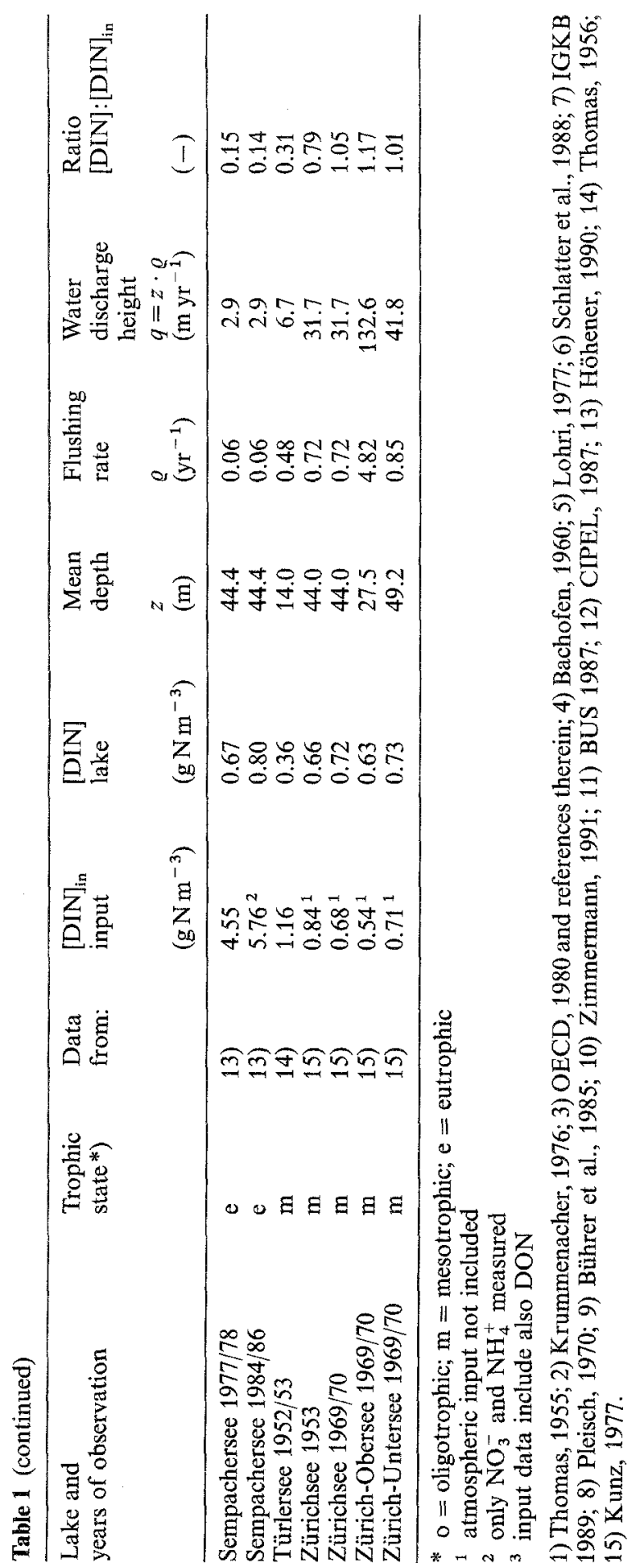



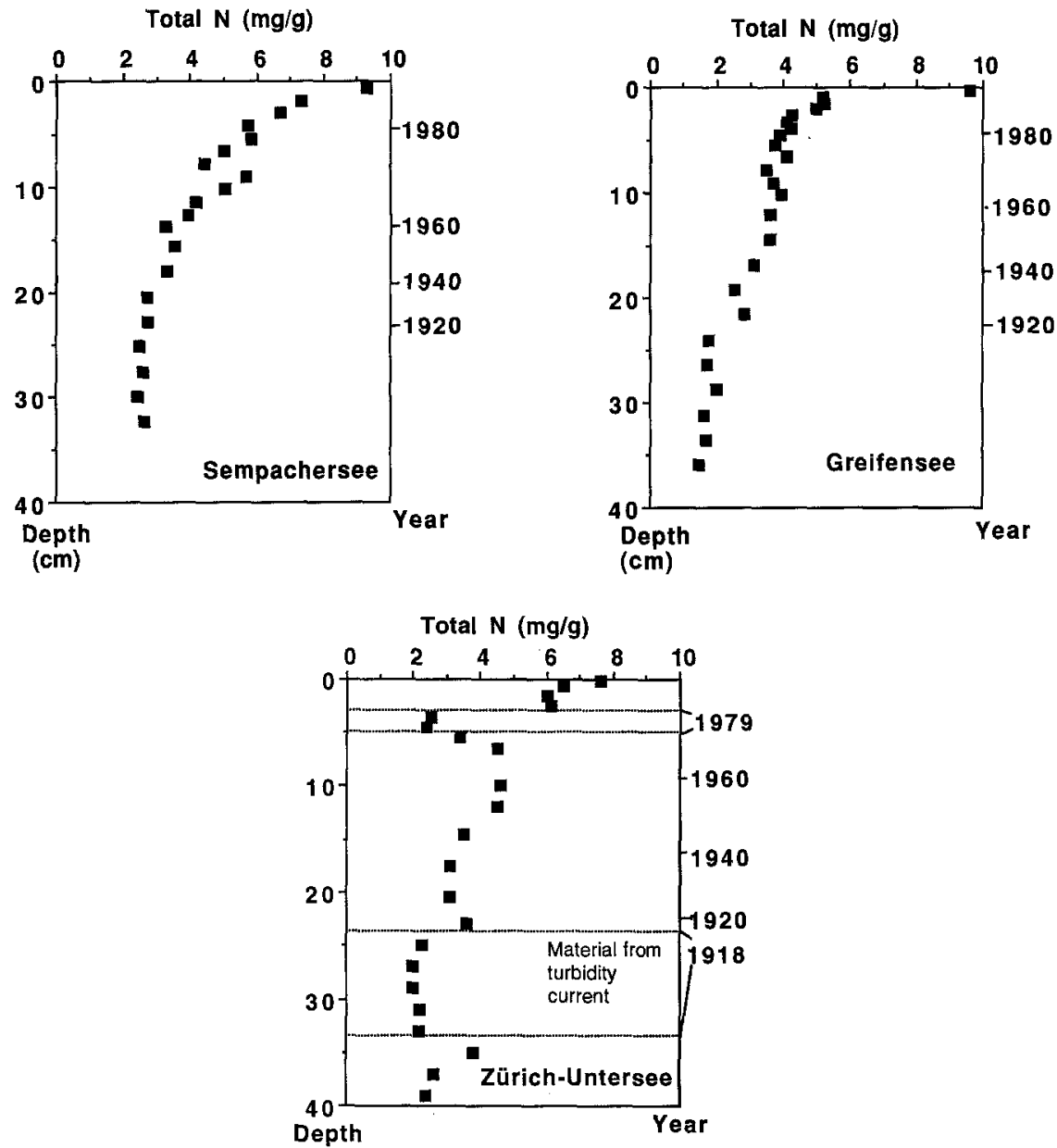

(cm)

Fig. 1a-c. Total $\mathrm{N}$ measured in dated sediment cores from the deepest locations of Sempachersee (1 a; lake depth $=87 \mathrm{~m}$ ), Greifensee $(1 \mathrm{~b} ; 32 \mathrm{~m})$ and Zürich-Untersee $(1 \mathrm{c} ; 132 \mathrm{~m})$. Areas between dotted lines (in 1c) refer to material brought in by lateral turbidity currents in 1979 and 1918

Sempachersee. Net $N$ sedimentation rates in the 3 eutrophic lakes are very similar (4.4 to $5 \mathrm{~g} \mathrm{~m}^{-2} \mathrm{yr}^{-1}$ ), although the [DIN] in these lakes differ by a factor of 2 (Table 1).

\section{3. $N$ sedimentation rates and gaseous $N$ loss rates estimated from $N$ - and $P$-mass balances}

In Table 3, calculated net $\mathrm{N}$ sedimentation rates and gaseous $\mathrm{N}$ loss rates are shown for 8 lakes on 10 occasions. Net $N$ sedimentation rates range from 0.47 to $10.3 \mathrm{~g} \mathrm{~m}^{-2} \mathrm{yr}^{-1}$. However, only in Alpnachersee it exceeded $6 \mathrm{~g} \mathrm{~m}^{-2} \mathrm{yr}^{-1}$. The sedimentation rates based on mass balances in Greifensee and Sempachersee do not 
Table 2. Estimation of net $N$ sedimentation rates in different lakes from sediment profiles of total $N$.

\begin{tabular}{|c|c|c|c|c|c|}
\hline Lake & Year & $\begin{array}{l}\text { Trophic } \\
\text { state }\end{array}$ & $\begin{array}{l}\text { Sedimentation } \\
\text { rate } \\
S \\
\left(\mathrm{~g} \mathrm{~m}^{-2} \mathrm{yr}^{-1}\right)\end{array}$ & $\begin{array}{l}\text { Total } \\
\text { nitrogen } \\
{[N]} \\
\left(\mathrm{mg} \mathrm{Ng}^{-1}\right)\end{array}$ & $\begin{array}{l}\text { Net } N \\
\text { sedimentation } \\
S_{\mathrm{net}}=S \cdot[N] \\
\left(\mathrm{g} \mathrm{N} \mathrm{m}^{-2} \mathrm{yr}^{-1}\right)\end{array}$ \\
\hline $\begin{array}{l}\text { Sempachersee } \\
\text { Sempachersee }\end{array}$ & $\begin{array}{l}1955 \\
1978\end{array}$ & $\begin{array}{l}\text { oligotrphic } \\
\text { eutrophic }\end{array}$ & $\begin{array}{l}770^{1} \\
770^{1}\end{array}$ & $\begin{array}{l}3.1 \\
5.7\end{array}$ & $\begin{array}{l}2.4 \\
4.4\end{array}$ \\
\hline $\begin{array}{l}\text { Greifensee } \\
\text { Greifensee }\end{array}$ & $\begin{array}{l}1950 \\
1978\end{array}$ & $\begin{array}{l}\text { eutrophic } \\
\text { eutrophic }\end{array}$ & $\begin{array}{l}1240^{2} \\
1240^{2}\end{array}$ & $\begin{array}{l}3.6 \\
4.0\end{array}$ & $\begin{array}{l}4.5 \\
5.0\end{array}$ \\
\hline $\begin{array}{l}\text { Zürich-Untersee } \\
\text { Zürich-Untersee }\end{array}$ & $\begin{array}{l}1950 \\
1980\end{array}$ & $\begin{array}{l}\text { meso/eutrophic } \\
\text { meso/eutrophic }\end{array}$ & $\begin{array}{l}790^{3} \\
790^{3}\end{array}$ & $\begin{array}{l}4.5 \\
6.0\end{array}$ & $\begin{array}{l}3,6 \\
4.7\end{array}$ \\
\hline
\end{tabular}

References and remarks:

${ }^{1}$ determined by varve counting (Höhener, 1990)

2 from Wan et al. (1987); determined independently by varve counting and radioisotopes

3 from Schuler et al. (1991); confirmed by Losher and Kelts (1989).

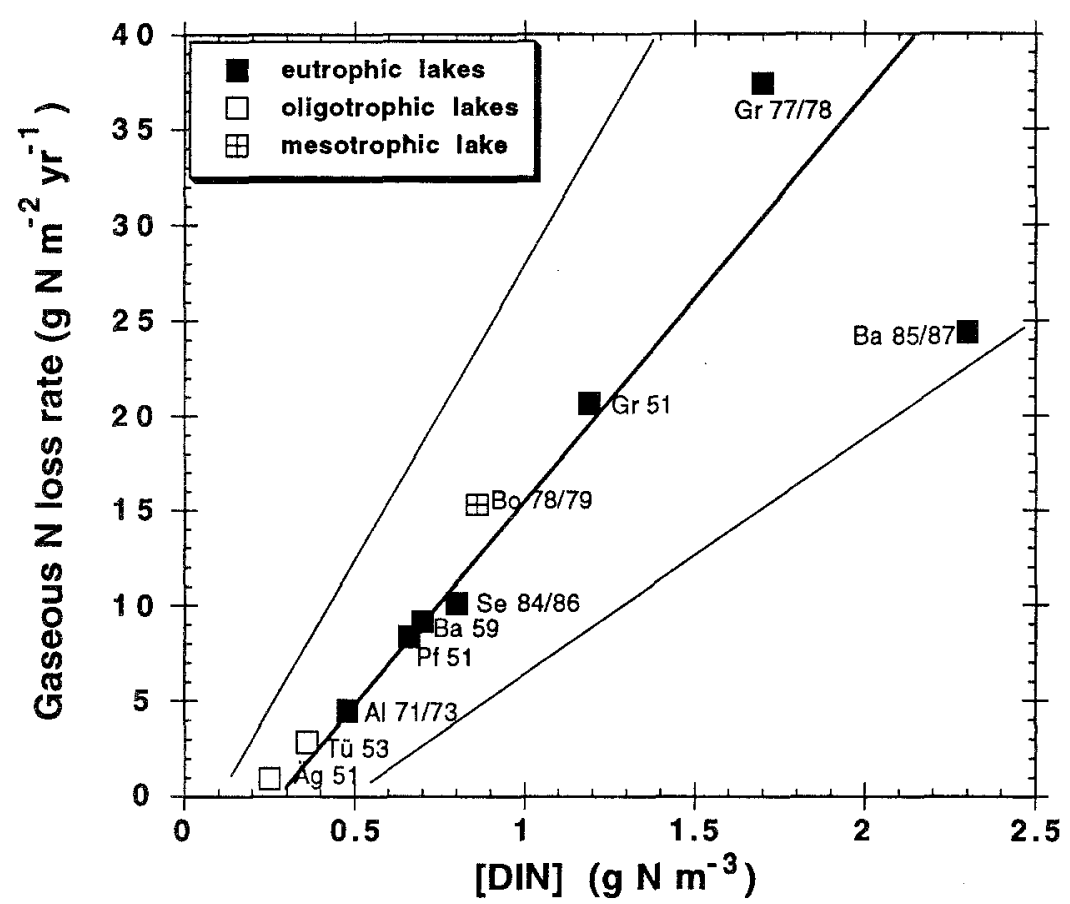

Fig. 2. Relationship between gaseous $\mathrm{N}$ loss rates (y) and mean dissolved inorganic nitrogen concentrations ([DIN], $x$ ) in seasonally stratified lakes. Linear regression (thick line) was calculated based on all data pairs shown $\left(\mathrm{y}=\mathrm{a}+\mathrm{bx}\right.$, with $\mathrm{a}=-5.59 \mathrm{~g} \mathrm{~m}^{-2} \mathrm{yr}^{-1}, \mathrm{~b}=20.41 \mathrm{~m} \mathrm{yr}^{-1}$ and $\left.r^{2}=0.755\right)$. Thin lines mark the $95 \%$ confidence limits for the slope $b$. Abbreviations refer to lake names in Table 3 


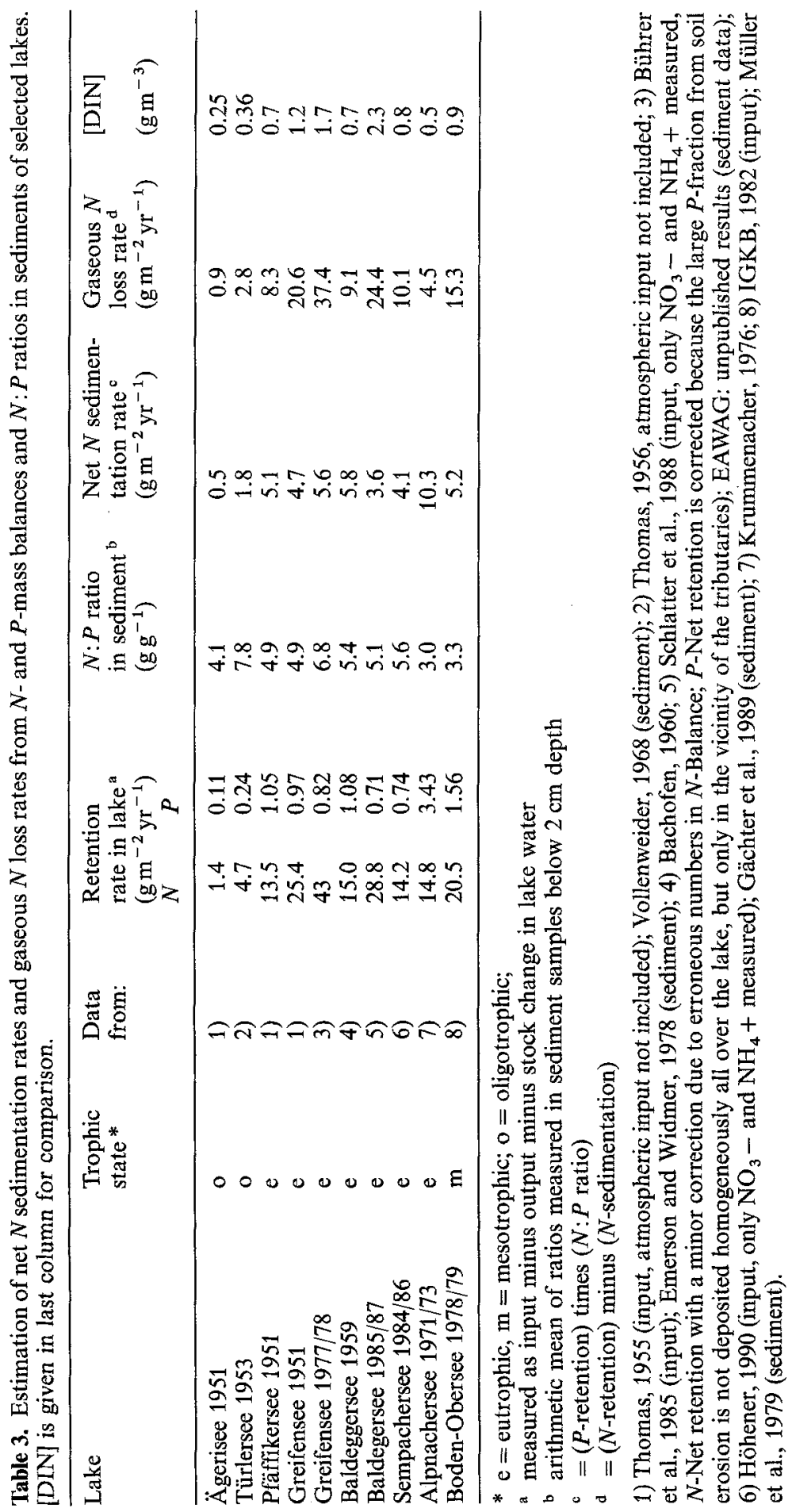


differ by more than $10 \%$ from sedimentation rates estimated from dated sediment cores (Table 2).

Gaseous $\mathrm{N}$ loss rates (Table 3 ) exceeded $\mathrm{N}$ sedimentation rates up to 7-fold, and in only one case (Alpnachersee) was the gaseous $\mathrm{N}$ loss rate lower than net $\mathrm{N}$ sedimentation rate, possibly because Alpnachersee receives high inputs of allochtonous particulate $\mathrm{N}$ (Krummenacher, 1976).

Gaseous $\mathrm{N}$ loss rates range from 0.93 to $37.4 \mathrm{~g} \mathrm{~m}^{-2} \mathrm{yr}^{-1}$ and show greater variability than net $\mathrm{N}$ sedimentation rates. Gaseous $\mathrm{N}$ loss rates in oligotrophic lakes were lower $\left(1.9 \pm 1.0 \mathrm{~g} \mathrm{~m}^{-2} \mathrm{yr}^{-1} ; \mathrm{n}=2\right)$ than in mesotrophic and eutrophic lakes, where a range from 4.5 to $37.4 \mathrm{~g} \mathrm{~m}^{-2} \mathrm{yr}^{-1}$ was calculated.

Gaseous $N$ loss rates (y) were significantly correlated with mean [DIN] (x) in the lakes (Fig. 2). The linear regression analysis yielded the relationship $y=a+b x$, with $a=-5.59 \mathrm{~g} \mathrm{~m}^{-2} \mathrm{yr}^{-1}, \mathrm{~b}=20.41 \mathrm{~m} \mathrm{yr}^{-1}$ and $\mathrm{r}^{2}=0.755$. The $95 \%$ confidence interval for the slope $\mathrm{b}$ lies between 11.7 and $26.7 \mathrm{~m} \mathrm{yr}^{-1}$.

\section{Discussion}

\section{1. [DIN] in European lakes}

An initial inspection of [DIN] in the observed lakes and the corresponding [DIN] $]_{\text {in }}$ suggests that [DIN] are related to $[\mathrm{DIN}]_{\text {in }}$ (Fig. 3). However, there is a considerable

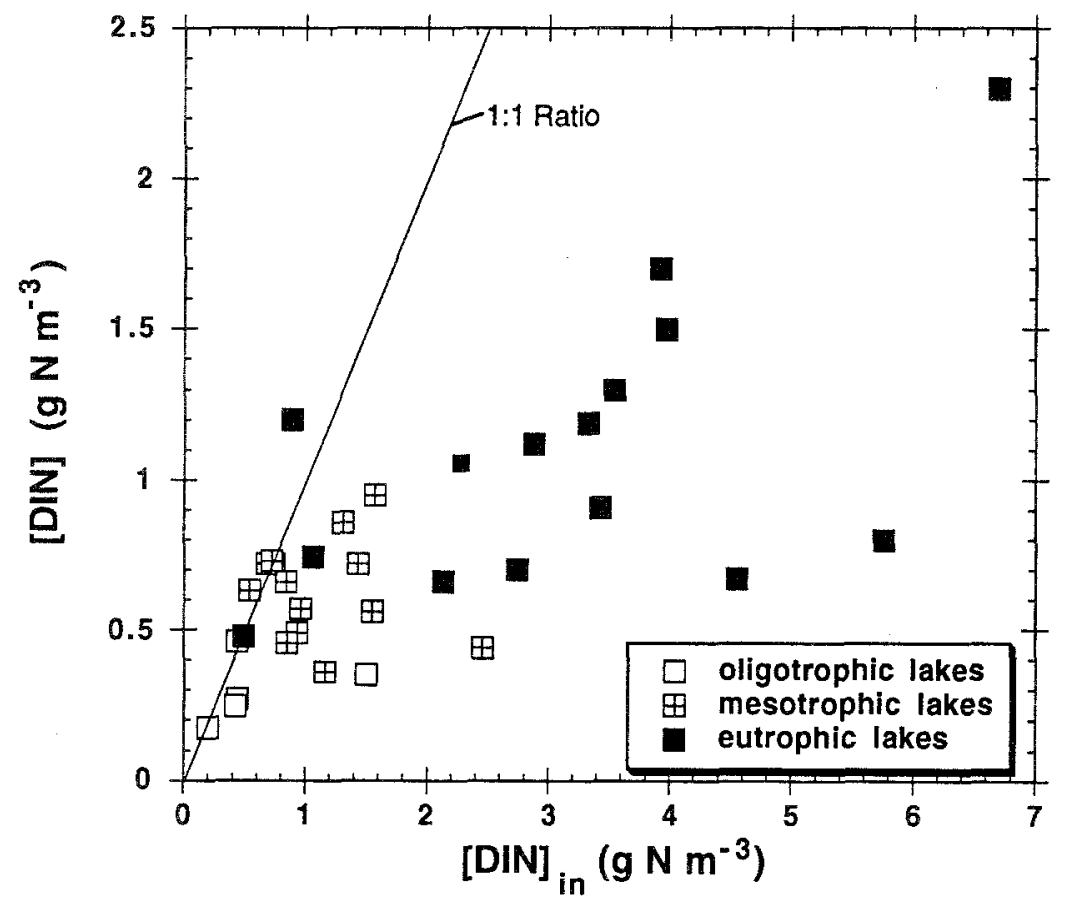

Fig. 3. Dissolved inorganic nitrogen concentrations ([DIN]) in seasonally stratified lakes of central Europe plotted versus mean input DIN concentrations $[\mathrm{DIN}]_{\text {in }}$ 
amount of scatter in the data. Mean inlake [DIN] may differ roughly by a factor of 3 in lakes with similar $[\mathrm{DIN}]_{\text {in }}$. Thus, for predictive purposes, a refined model must be applied. Because empirical correlations do not contribute to any understanding of the processes involved in DIN cycling in the lakes, it was not attempted to find empirical or stochastic relationships. Identification and quantification of the $\mathrm{N}$ removal processes in lakes and their rate dependency upon lake morphometric parameters, [DIN], and lake trophic state is a more powerful approach for modelling [DIN] in lakes. These processes and mechanisms should be included into a mass transport model.

\section{2. $N$ removal processes}

\subsubsection{Net $\mathrm{N}$ sedimentation}

$\mathrm{N}$ burial rates obtained from sediment cores sampled at the deepest point of a lake are a measure of $\mathrm{N}$ sedimentation at this point of the lake, whereas net sedimentation rates obtained from $\mathrm{N}$ and $\mathrm{P}$ mass balances give an area-integrated value. However, the two different methods both provided approximate equal rates in Sempachersee as well as in Greifensee (compare Table 2 and 3), suggesting a homogeneous $\mathrm{N}$ sedimentation.

$\mathrm{N}$ burial rates are very similar in eutrophic lakes independent of the [DIN]. Summing up the estimations by both methods (Tables 2 and 3), net $\mathrm{N}$ sedimentation rates are higher in meso- and eutrophic lakes (Mean: 5.1; SD: $\pm 1.6 \mathrm{~g} \mathrm{~m}^{-2} \mathrm{yr}^{-1}$; $\mathrm{n}=13)$ than in the oligotrophic lakes $\left(1.6 \pm 1.0 \mathrm{~g} \mathrm{~m}^{-2} \mathrm{yr}^{-1} ; \mathrm{n}=3\right)$, suggesting that a higher primary production leads to a greater incorporation of $\mathrm{N}$ into the sediments. Primary production is known to depend on total $\mathrm{P}$ concentrations in lakes. Fricker (OECD 1980 ) showed that this relationship can be modeled by a Monod-type kinetic expression (Fig. 4). Figure 4 suggests that net $\mathrm{N}$ sedimentation rates depend on total $\mathrm{P}$ concentrations at spring overturn in a manner similar to primary production. Alpnachersee is an exception because of observed high inputs of allochtonous material. It can be estimated from Fig. 4 that the ratio of fixed carbon in primary production to $\mathrm{N}$ buried in the sediments is $66.6 \mathrm{~g} \mathrm{Cg}^{-1} \mathrm{~N}$ or $77.7 \mathrm{MolC} \mathrm{Mol}^{-1} \mathrm{~N}$.

$\mathrm{N}$ buried in sediments includes either refractory organic $\mathrm{N}$ compounds or ammonia adsorbed onto minerals or dissolved in the interstitial water. A higher primary production by algae leads to synthesis of a higher total amount of potentially refractory organic-N-containing material. Also, a greater level of $\left[\mathrm{NH}_{4}^{+}\right]$in the interstitial waters of eutrophic lakes with high sedimentation rates of organic detritus favors $\mathrm{NH}_{4}^{+}$-adsorption onto clay minerals. Therefore, a difference in net $\mathrm{N}$ sedimentation rates between eutrophic and oligotrophic lakes should be expected. That explains the observed increase of total $\mathrm{N}$ in the sediment record during progressive eutrophication (Fig. 1). 


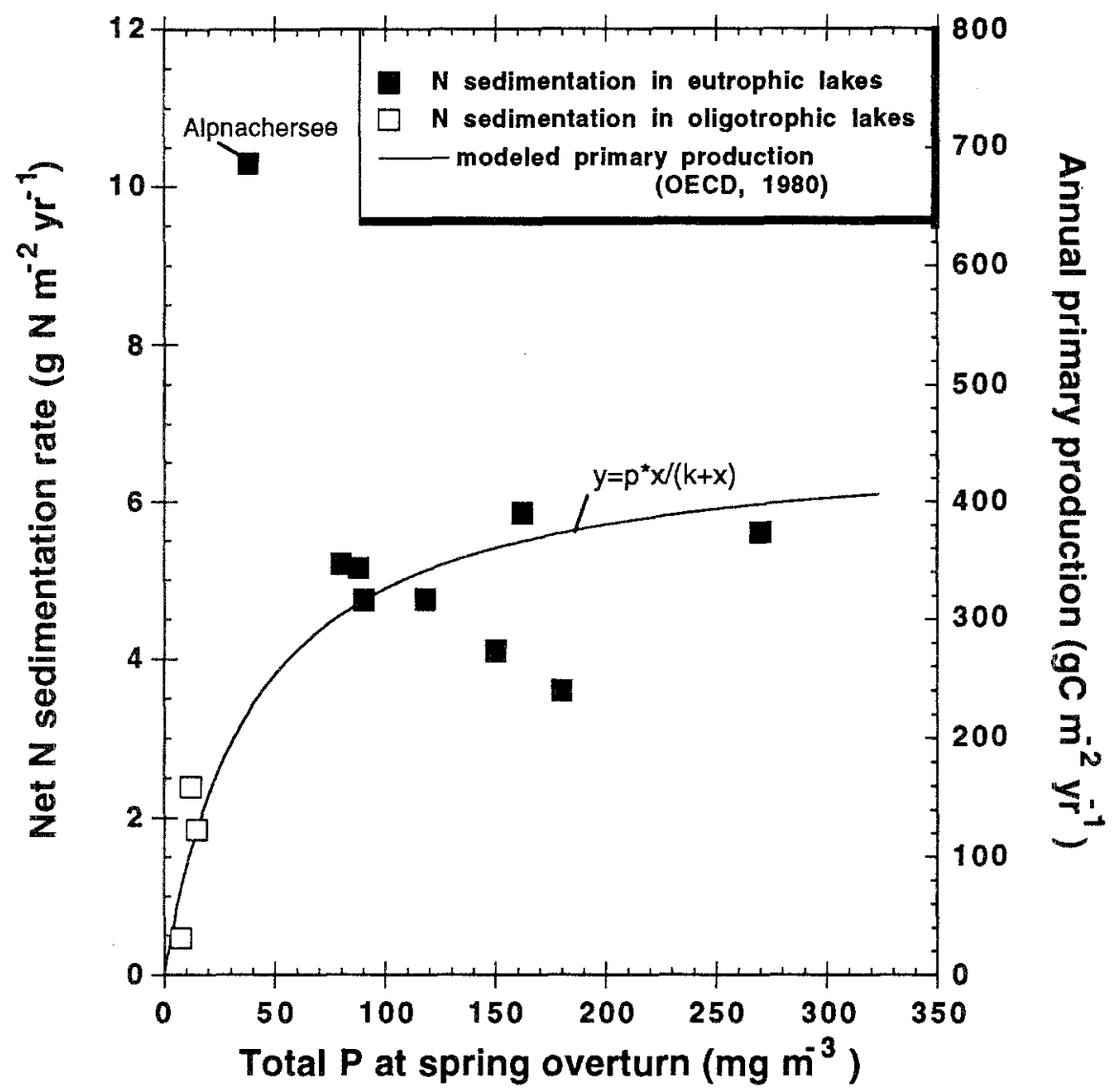

Fig. 4. Net $\mathrm{N}$ sedimentation rates (squares; data from Tables 2 and 3 ) and annual gross (total) primary production (solid line: OECD model curve $\mathrm{y}=\mathrm{p} \cdot \mathrm{x} /(\mathrm{k}+\mathrm{x})$ with $\mathrm{p}=456 \mathrm{~g} \mathrm{C} \mathrm{m}^{-2} \mathrm{yr}^{-1}$ and $\mathrm{k}=40 \mathrm{mg} \mathrm{P} \mathrm{m}^{-3}$ ) versus total $\mathrm{P}$ concentration at spring overturn, measured in the same years as $\mathrm{N}$ sedimentation

\subsubsection{Gaseous $N$ loss}

Experimental measurement of gas exchange rates at the air-water interface are very difficult to achieve and have so far not been used to quantify the exchange rate of $\mathrm{N}_{2}$ across lake surfaces. The reason for this is the high saturation concentration of $\mathrm{N}_{2}$ in water, which is about 2 orders of magnitude larger than changes in concentrations due to microbial $\mathrm{N}_{2}$ production (denitrification) or $\mathrm{N}_{2}$ consumption $\left(\mathrm{N}_{2}\right.$-fixation). Gas exchange rates of other, quantitatively less important $\mathrm{N}$ compounds (e.g. $\mathrm{N}_{2} \mathrm{O}$ ) have been quantified in lakes with only low accuracy because of uncertainties in the transfer velocity across the air-water interface (Lemon and Lemon, 1981; Knowles et al., 1981).

In this study, an indirect approach using combined N/P mass balances has therefore been used to quantify gaseous $\mathrm{N}$ loss rates. Several problems affecting the 
accuracy of this method are involved: 1) measurements of $\mathrm{N}$ and $\mathrm{P}$ input from lake tributaries and measurement of direct atmospheric input to the lake surface is methodologically difficult and may be significantly wrong; 2) distribution of $\mathrm{N}$ and $\mathrm{P}$ and consequently the $\mathrm{N}: \mathrm{P}$ ratio in sediments may be spatially inhomogeneous; e.g. Prich particulate fractions may be deposited in the vicinities of the tributaries, and 3) $\mathrm{N}$ and $\mathrm{P}$ in the sediments may be differentially mobilized and internally recycled therefore total $\mathrm{N}: \mathrm{P}$ ratios in sediments are not similar to refractory $\mathrm{N}: \mathrm{P}$ ratios. For the reasons cited above, gaseous $\mathrm{N}$ loss rates determined by mass balances may be affected by significant errors. Nevertheless, they are the only time- and areaintegrated estimates available.

For all lakes, a net gaseous $\mathrm{N}$ loss rate from the lake to the atmosphere was calculated, indicating that gaseous loss rates $\left(\mathrm{N}_{2}, \mathrm{~N}_{2} \mathrm{O}, \mathrm{NO}, \mathrm{NH}_{3}\right)$ exceed $\mathrm{N}_{2}$ fixation rates, which were not included in input data. Rates of $\mathrm{N}_{2}$-fixation in lakes have been measured by various authors using the acetylene method (Howarth et al., 1988). Reported $\mathrm{N}_{2}$-fixation rates range from $<0.1 \mathrm{~g} \mathrm{~m}^{-2} \mathrm{yr}^{-1}$ in oligotrophic lakes up to 0.2 to 2.6 in eutrophic north temperate lakes (Howarth et al., 1988). $\mathrm{N}_{2}$-fixation rates in these central European lakes were not measured, but a comparison of the rates cited above with estimated gaseous $\mathrm{N}$ loss rates of 1.9 to $37.4 \mathrm{~g} \mathrm{~m}^{-2} \mathrm{yr}^{-1}$ indicates that $\mathrm{N}_{2}$-fixation contributes only a minor part to overall gas exchange. Also, the exchange of $\mathrm{NH}_{3}$ did not contribute significantly to mass balances of $\mathrm{N}$, when concentrations of dissolved $\mathrm{NH}_{4}^{+}$in the epilimnion of Sempachersee were compared to the partial pressures of $\mathrm{NH}_{3}$ in the atmosphere (Höhener, 1990). Thus, the majority of gaseous $\mathrm{N}$ evolving from seasonally stratified, northtemperate lakes must be $\mathrm{N}_{2}, \mathrm{~N}_{2} \mathrm{O}$, or possibly NO. These gases are the product of either denitrification (Knowles, 1982), or nitrification (Goreau et al., 1980), or a combination of both. Active denitrification is normally observed in anaerobic hypolimnia or sediments (Seitzinger, 1988), whereas nitrification is restricted to aerobic zones (Kaplan, 1983).

Figure 2 indicates that 1 ) gaseous $\mathrm{N}$ loss rates are positively related to inlake [DIN], and 2) gaseous $\mathrm{N}$ loss rates may be zero at low inlake [DIN]. For these findings, the following explanations are proposed:

Denitrification in anaerobic sediments and also in anaerobic hypolimnia converts $\mathrm{NO}_{3}^{-}$to gaseous $\mathrm{N}$ forms and normally consumes the majority of $\mathrm{NO}_{3}^{-}$in the anaerobic zones. Therefore, $\mathrm{NO}_{3}^{-}$must be fueled from upper water layers to denitrifying microorganisms within the anaerobic zones. An experiment with isotopically marked ${ }^{15} \mathrm{NO}_{3}^{-}$in a sediment water incubation system showed that more than $88 \%$ of the labelled $\mathrm{NO}_{3}^{-}$diffusing from overlying aerobic water into anaerobic sediment of Sempachersee was converted to gaseous N (Höhener, 1990). In addition, flux chamber experiments in Sempachersee always showed a linear relationship between the rate of $\mathrm{NO}_{3}^{-}$consumption by the sediment and $\left[\mathrm{NO}_{3}^{-}\right]$in the overlying water (Höhener, 1990). Knowing that virtually all of the $\mathrm{NO}_{3}^{-}$consumed in the sediment is converted to gases, a positive correlation between $\mathrm{N}$ gas production and $\left[\mathrm{NO}_{3}^{-}\right]$in aerobic bottom lake water is postulated. Since $\mathrm{NO}_{3}^{-}$usually dominates over other inorganic nitrogen forms in lakes with permanently aerobic hypolimnia, this positive correlation had to be expected. 
A detailed study of Sempachersee (Höhener, 1990) showed that mean $\mathrm{NO}_{3}^{-}$ consumption rates of hypolimnetic sediments equalled $\mathrm{N}$ loss rates across the airwater interface. This suggests that production of gaseous $\mathrm{N}$ species mainly occurred as a result of sediment denitrification. Measured denitrification rates in various eutrophic lakes ranging from 5.2 to $21 \mathrm{mg} \mathrm{m}^{-2} \mathrm{yr}^{-1}$ (Seitzinger, 1988) are in the same order of magnitude as calculated gaseous $\mathrm{N}$ loss rates (Table 3 ). However, the gases $\mathrm{N}_{2} \mathrm{O}$ and $\mathrm{NO}$ can also be formed by nitrification (Goreau et al. 1980), usually active in the hypolimnia of lakes. Thus nitrogen might also be lost to the atmosphere as $\mathrm{N}_{2} \mathrm{O}$ and NO (Knowles et al., 1981; Yoh et al., 1988). Unfortunately, the quantitative contribution of $\mathrm{N}_{2} \mathrm{O}$ and $\mathrm{NO}$ to total gaseous $\mathrm{N}$ loss of lakes is not yet understood.

In oligotrophic lakes, the amount of organic material settling to the lake bottom is small, so that eventually all of it is mineralized with oxygen as electron acceptor. Therefore, denitrification may be inhibited due to the lack of organic substrata. This might explain why gaseous $\mathrm{N}$ loss rates are potentially zero at $[\mathrm{DIN}]<0.3 \mathrm{~g} \mathrm{~m}^{-3}$ in oligotrophic lakes. Measured denitrification rates in various, mainly shallow, oligo/mesotrophic lakes range from 0.6 to $6.7 \mathrm{mg} \mathrm{m}^{-2} \mathrm{yr}^{-1}$ (Seitzinger, 1988) and are in the same order of magnitude as the gaseous $\mathrm{N}$ loss rates reported for the two oligotrophic lakes in Fig. 2.

The range of gaseous $\mathrm{N}$ loss rates can be estimated using the $95 \%$ confidence interval for the slope $b$ in Fig. 2. This estimation gives first order rate constants between 11.7 and $26.7 \mathrm{~m} \mathrm{yr}^{-1}$ (Fig. 2). At high [DIN], data points deviate from an average trend. Greifensee (Gr 77/78) and Baldeggersee (Ba 85/87) had different redox conditions in their hypolimnia; Greifensee was seasonally anoxic, while Baldeggersee was at that time permanently oxic due to artificial hypolimnetic oxygenation (Stadelmann et al., 1984). Oxygenation could account for lower denitrification rates in Baldeggersee.

A first order relationship for overall nitrate removal has also been observed in acid-sensitive shallow lakes (Kelly et al., 1987) with mass transfer coefficients ranging from 2.3 to $12.9 \mathrm{~m} \mathrm{yr}^{-1}$. It must be pointed out, however, that those rates describe the sum of net $\mathrm{N}$ sedimentation and gas loss, whereas the first order relationship in Fig. 2 only describes $\mathrm{N}$ gas loss.

\subsection{A one box model integrating rates of $N$ removal processes into lake mass balances}

A mass balance for DIN in lakes consists of at least five terms: input, output through the effluent, net sedimentation, gaseous $\mathrm{N}$ loss, and mass change in the water body (Fig. 5). DIN input to the lake surface through precipitation must be included in the input term. From conservation of mass, the sum of these five terms must equal zero.

Mathematically, input and output can be expressed as products of the mean flow rate $\mathrm{Q}\left(\mathrm{m}^{3} \mathrm{yr}^{-1}\right)$ and mean $[\mathrm{DIN}]_{\text {in }}$ or mean [DIN]. The restrictive assumption that $[D I N]$ in output equals inlake [DIN] is an oversimplification for lakes with strong horizontal inhomogeneities and a strong vertical stratification (Vollenweider, 1975).

The two $\mathrm{N}$ removal processes in the lake will both be expressed in proportion to lake surface area, which is a reasonable approximation of the lake sediment area. Net $\mathrm{N}$ sedimentation rate was shown to be independent of [DIN], but to depend on 


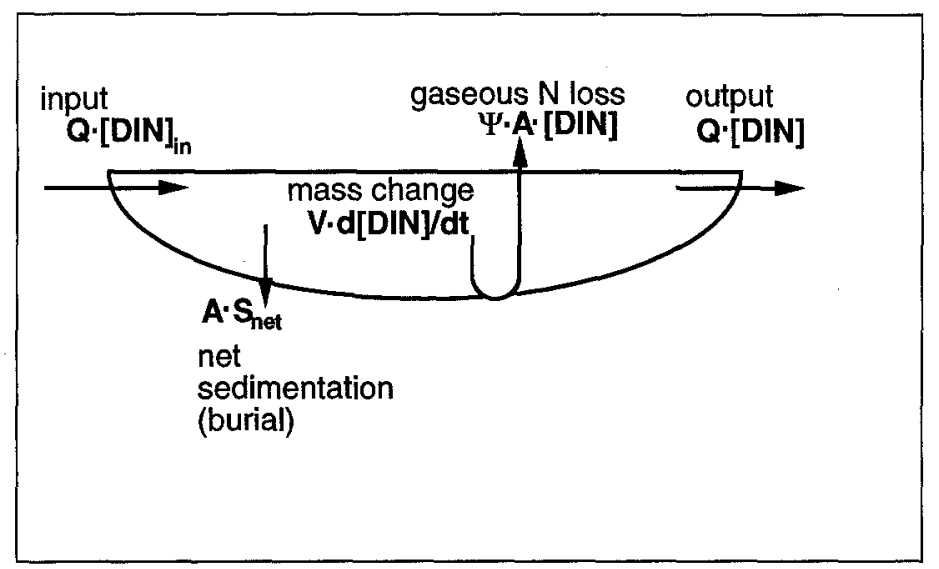

Fig. 5. Schematic representation of the one box mass balance model for DIN in lakes. $Q$ : flow rate, $A$ : lake surface area, $V$ : lake volume, $S_{\text {net }}$ : net sedimentation rate (burial rate) $\Psi$ : transfer velocity for gas loss, [DIN] and $[\mathrm{DIN}]_{\text {in }}$ : mean dissolved inorganic nitrogen concentrations in lake and in inputs

trophic state. For a given trophic state, it can be expressed as a constant rate, $S_{\text {net }}$ (unit: $\mathrm{g} \mathrm{m}^{-2} \mathrm{yr}^{-1}$ ). Since gaseous $\mathrm{N}$ loss rates are a function of [DIN], $G_{\text {out }}$, can best be described as a first order reaction:

$$
G_{\mathrm{out}}=\Psi \cdot[\mathrm{DIN}]
$$

where $\Psi$ is a first order rate constant (transfer velocity, unit: $\mathrm{m} \mathrm{yr}^{-1}$ ). However, this transfer velocity can not be compared to gas transfer velocities because it reflects the reaction rates of DIN components to gaseous $\mathrm{N}$ (limited probably by the diffusion of $\mathrm{NO}_{3}^{-}$to the anaerobic zones where it is reduced) and not gas transport at the airwater interface based on gradients and Henry's law. $\Psi$ can be visualized as the height of a column, from which DIN is removed by conversion to gaseous $\mathrm{N}\left(\mathrm{N}_{2}, \mathrm{~N}_{2} \mathrm{O}\right.$ and NO) in one year.

In summary, the mass balance equation for DIN in lakes can be written as follows:

$$
V d[\mathrm{DIN}] / \mathrm{d} t=Q[\mathrm{DIN}]_{\mathrm{in}}-Q[\mathrm{DIN}]-S_{\mathrm{net}} A-\Psi[\mathrm{DIN}] A
$$

where all the variables were previously defined except $V$ (=lake volume) and $A$ (= lake surface area). The left hand side of equation 2 is zero for lakes at steady state with respect to [DIN]. A solution for steady state [DIN] in the lake is found when equation 2 is divided by $V, Q / V$ is replaced by $\varrho$, the hydraulic flushing rate, and $A / V$ by $1 / z$, the inverse of the mean depth:

$$
\text { steady state }[\mathrm{DIN}]=\frac{[\mathrm{DIN}]_{\mathrm{in}} \varrho-\frac{S_{\mathrm{net}}}{z}}{\varrho+\frac{\Psi}{z}}
$$


Therefore, steady state $[D I N]$ is a function of 1) input $[D I N]_{\text {in }}, 2$ ) removal rates represented by the constant net sedimentation rate $S_{\text {net }}$ and the transfer velocity for gaseous $\mathrm{N}$ loss, $\Psi$, and 3 ) the hydraulic flushing rate $\varrho$ and the morphometric parameter mean depth, $z$. Equation 3 is useful to estimate the relative contribution of net sedimentation or gaseous $\mathrm{N}$ loss to the hypothetical steady state [DIN] in a lake given its $[\mathrm{DIN}]_{\text {in }}$ and morphometric and hydraulic properties $\varrho$ and $z$. Multiplying the numerator of equation 3 by $z$, it can be seen that $S_{\text {net }}$ is unimportant for steady state $[\mathrm{DIN}]$ if:

$$
[\mathrm{DIN}]_{\text {in }} \varrho z \gg S_{\mathrm{net}}
$$

This means that net $\mathrm{N}$ sedimentation has little effect on steady state [DIN] in comparatively deep, intensively flushed lakes with high $[D I N]_{\text {in }}$. Inversely, net sedimentation is the dominating factor controlling [DIN] in comparatively shallow lakes with high water renewal times and low $[\mathrm{DIN}]_{\text {in }}$.

By multiplying the denominator of equation 3 by $z$, it is shown that $\Psi$ has no impact on steady state [DIN] if

$$
\varrho z \gg \Psi
$$

Gaseous N loss is an important process for steady state [DIN] in shallow lakes with high water renewal times and is unimportant in deep, intensively flushed lakes.

Consequently, steady state $[\mathrm{DIN}]$ is critically dependent on the relative magnitudes of the removal rate constants compared to the product of hydraulic flushing rate and mean depth. The latter product has the units of a velocity $\left(\mathrm{m} \mathrm{yr}^{-1}\right)$ and, according to Vollenweider (1975), is called the lake's water discharge height. It is better understood in terms of a unit volume of water added to a unit surface area of the lake (e.g. $\mathrm{m}^{3}$ water discharge heights in order to relate $[D I N]$ to $[D I N]_{\text {in }}$. In Figure 6, the ratio of removal processes, net sedimentation and gaseous $\mathrm{N}$ loss, have little impact on steady state [DIN].

Being the critical parameter, it seems obvious to classify lakes according to their water discharge heights in order to relate $[D I N]$ to $[D I N]_{\text {in }}$. In Figure 6, the ratio of $[D I N]$ to $[D I N]_{\text {in }}\left([D I N]:[D I N]_{\text {in }}\right)$ is plotted versus typical water discharge heights in deep lakes (1 to $200 \mathrm{~m} \mathrm{yr}^{-1}$ ).

In lakes with water discharge heights larger than $50 \mathrm{~m}$ per year, inlake [DIN] do not differ by more than $20 \%$ from $[\mathrm{DIN}]_{\text {in }}$, indicating that net sedimentation and gaseous $\mathrm{N}$ loss are of relatively little importance. On the other hand, in lakes with water discharge heights of less than $\approx 50 \mathrm{~m}$ per year, $\mathrm{N}$ removal processes are contributing to a significant decrease of the inlake $[D I N]$ relative to mean $[D I N]_{\text {in }}$.

In Figure 6, lines which illustrate the influence of the removal rates on the ratio $[D I N]:[D I N]_{\text {in }}$ are drawn. These lines help to verify the setup of the model and the generalizations of the observed removal rates by testing the whole database of deep, seasonally stratified European lakes from Table 1. Line $a$ illustrates the simple case, where no $\mathrm{N}$ removal takes place in the lakes (input $=$ output). Line $b$ shows a case, where net $\mathrm{N}$ sedimentation, independent on [DIN], is the only removal process. Line $c$ and $d$ consider both net $\mathrm{N}$ sedimentation and $\mathrm{N}$ gas loss. The first order rate 
constants $\Psi$ for gas loss are assumed as 10 and $25 \mathrm{~m} \mathrm{yr}^{-1}$ for the lines $c$ and $d$, respectively. These values for $\Psi$ were taken from estimations of $\Psi$ in Fig. 2.

Attersee and Zürichsee (Ober- and Untersee) are the lakes where inlake [DIN] exceed $[\mathrm{DIN}]_{\text {in }}$ suggesting either a high rate of $\mathrm{N}_{2}$-fixation or erroneous DIN input data. Attersee has a theoretical water residence time of 7 years and may therefore be far from steady state with regard to [DIN].

All data points from oligothrophic lakes are situated on the left hand side of line $c$ in Fig. 6. suggesting lower values for $S_{\text {net }}$ and/or $\Psi$ than taken for calculation of line $c$. All data points from eutrophic lakes except Hallwilersee and Alpnachersee are situated between the lines $c$ and $d$ in Fig. 6, indicating that generally, the $\mathrm{N}$ removal rates in eutrophic lakes are within rates used for calculation of lines $c$ and $d$. The reasons why Hallwilersee and Alpnachersee have somewhat higher [DIN] than expected are not known. The four data points from Sempachersee at the lowest observed water discharge height illustrate, how the ratio $[\mathrm{DIN}]:[\mathrm{DIN}]_{\text {in }}$ decreases with progressive eutrophication.

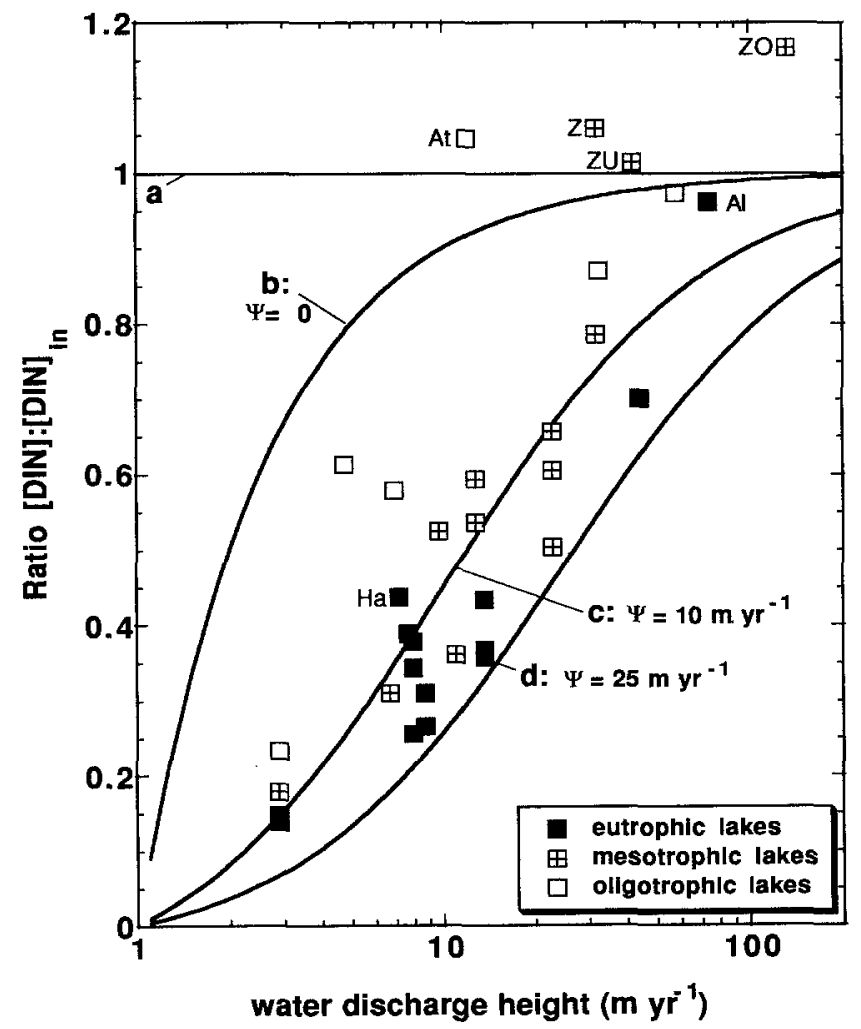

Fig. 6. Ratio of inlake to input DIN concentrations ([DIN]: $[D I N]_{\text {in }}$ ) in seasonally stratified lakes of central Europe versus the mean water discharge height. Lines $a-d$ were calculated with equation (3) assuming [DIN $]_{\text {in }}=3 \mathrm{~g} \mathrm{~m}^{-3}$ and: $a: S_{\text {net }}=0 \mathrm{~g} \mathrm{~m}^{-2} \mathrm{yr}^{-1} ; \Psi=0 \mathrm{~m} \mathrm{yr}^{-1}$ (no $\mathrm{N}$ removal processes); $b: S_{\text {net }}=3 \mathrm{~g} \mathrm{~m}^{-2} \mathrm{yr}^{-1} ; \Psi=0 \mathrm{~m} \mathrm{yr}^{-1}$ (no $\mathrm{N}$ gas loss) $c: S_{\text {net }}=3 \mathrm{~g} \mathrm{~m}^{-2} \mathrm{yr}^{-1} ; \Psi=10 \mathrm{~m} \mathrm{yr}^{-1} ; d:$ $S_{\text {net }}=3 \mathrm{~g} \mathrm{~m}^{-2} \mathrm{yr}^{-1} ; \Psi=25 \mathrm{~m} \mathrm{yr}^{-1}$ 


\section{Conclusions}

Two different and independent removal processes for $\mathrm{N}$, sedimentation and gas loss, are responsible for considerable lower [DIN] in lakes compared to [DIN] in the inflows. So, lakes function as $\mathrm{N}$ elimination reactors preventing DIN from being transported to coastal marine ecosystems where they potentially contribute to eutrophication (Ryther and Dunstan, 1971; Gerlach, 1989; Enoksson et al., 1990). The end products of the DIN removal processes in lakes either can be buried in sediments as organic $\mathrm{N}$ or ammonium, or be released to the atmosphere as $\mathrm{NH}_{3}, \mathrm{~N}_{2}, \mathrm{~N}_{2} \mathrm{O}$ or NO. This paper focuses on the topics of $\mathrm{N}$ burial in sediments and total $\mathrm{N}$ gas loss from deep, stratified lakes to the atmosphere. More work is needed to understand the speciation of the gases lost to the atmosphere.

Net $\mathrm{N}$ sedimentation rates in eutrophic lakes appear to be independent of [DIN] in the concentration range of $0.67-1.7 \mathrm{~g} \mathrm{~m}^{-3}$, whereas gaseous $\mathrm{N}$ loss rates are positively dependent on mean [DIN] in a range from 0.3 to $2.3 \mathrm{~g} \mathrm{~m}^{-3}$ (Table 3). The estimated first order removal rate constants for $\mathrm{N}$ gas are transfer velocities. Removal constants for $\mathrm{N}$ gas loss (transfer velocities) range from 11.7 to $26.7 \mathrm{~m} \mathrm{yr}^{-1}$. They can best be understood in thinking of the height of a water column, from which DIN is converted to gaseous $\mathrm{N}$ yearly. In eutrophic lakes with water discharge heights in the same order of magnitude than $\mathrm{N}$ gas transfer velocities, conversion of DIN to gaseous $\mathrm{N}$ therefore is an effective removal mechanism. In lakes with high [DIN], gaseous $\mathrm{N}$ loss rates were calculated to exceed net $\mathrm{N}$ sedimentation rates manyfold.

DIN removal is larger in eutrophic lakes. So, a high primary production has a positive effect on the capacity of such lakes to remove DIN from their water bodies. In many eutrophic lakes, restoration measures have been applied in order to decrease $P$ input and thereby decrease primary production. According to these findings, as a consequence of decreased primary production, [DIN] will increase in lakes with water discharge heights not exceeding $\approx 50 \mathrm{~m} \mathrm{yr}^{-1}$, even if $[D I N]_{\text {in }}$ is kept constant.

\section{ACKNOWLEDGEMENTS}

The authors thank E. Wieland and A. Losher for cooperating in sediment core collection and analysis and D. Imboden for helpful discussions. D. Adams and N. Urban helped with critical remarks and improved the manuscript. This work was supported by an EAWAG Ph-D-Grant.

\section{REFERENCES}

Bachofen, R., 1960. Stoffhaushalt and Sedimentation im Baldegger- und Hallwilersee. Ph. D. dissertation University of Zürich, $118 \mathrm{pp}$.

Bührer, H., 1979. Die Berechnung der totalen Menge gelöster Stoffe in Seen. Schweiz. Z. Hydrol. $41: 418-420$.

Bührer, H., E. Szabo, H. Ambühl, 1985. Die Belastung des Greifensees mit Phosphor, Stickstoff, geochemischen Stoffen und Schwermetallen in den Jahren 1977/78. Schriftenreihe der EAWAG 1:50 pp.

BUS (Bundesamt für Umweltschutz) 1987. Lac de Neuchâtel: Etude des affluents. Schriftenreihe Umweltschutz 65:44 pp. 
CIPEL (Commission internationale pour la protection des eaux du Léman contre la pollution) 1987. Rapport sur les études et recherches entreprises dans le bassin lémanique. Programme quinquennal 1981-1985. Lausanne, $222 \mathrm{pp}$.

Emerson, S., G. Widmer, 1978. Early diagenesis in anaerobic lake sediments. II. Thermodynamic and kinetic factors controlling the formation of iron phosphate. Geochim. Cosmochim. Acta 42:1307-1316.

Enoksson, V., F. Sörensson, W. Graneli, 1990. Nitrogen transformations in the Kattegat. Ambio 19:159-166.

Gerlach, S. A., 1989. Mutmassliche Auswirkungen des Nährstoffeintrags in die Nordsee. Münchner Beiträge zur Abwasser-, Fischerei- und Flussbiologie 43:89-98.

Gächter, R., 1968. Phosphorhaushalt und planktische Primärproduktion im Vierwaldstättersee (Horwer Bucht). Ph. D. dissertation ETH Nr. 4127, 66 pp.

Gächter, R., S. I. Meyer, A. Mares, 1988. Contribution of bacteria to release and fixation of phosphorus in lake sediments. Limnol. Oceanogr. 33:1542-1558.

Gächter, R., A. Mares, E. Grieder, A. Zwyssig, P. Höhener, 1989. Auswirkungen der Belüftung und Sauerstoffbegasung auf den P-Haushalt des Sempachersees. Eine Zwischenbilanz nach fünf Jahren Betriebsdauer. Wasser - Energie - Luft 81:335-341.

Goreau, T. J., W. A. Kaplan, S. C. Wofsy, M. B. McElroy, F. W. Valois, S. W. Watson, 1980. Production of $\mathrm{NO}_{2}^{-}$and $\mathrm{N}_{2} \mathrm{O}$ by nitrifying bacteria at reduced concentrations of oxygen. Appl. Environ. Microbiol. 40:526-532.

Höhener, P., 1990. Der Stickstoffhaushalt von Seen, illustriert am Beispiel des Sempachersees. Ph. D. dissertation ETH Nr. 9157, 132 pp.

Howarth, R. W., R. Marino, J. Lane, J. J. Cole, 1988. Nitrogen fixation in freshwater, estuarine, and marine ecosystems. 1. Rates and importance. Limnol. Oceanogr. 33/4, part 2:669-687.

IGKB (Internationale Gewässerschutzkommission für den Bodensee), 1982. Die Belastung des Bodensees mit Phosphor- und Stickstoffverbindungen und organischem Kohlenstoff im Abflussjahr 1978/79. Bericht Nr. 28, 68 pp.

IGKB (Internationale Gewässerschutzkommission für den Bodensee), 1989. Die Belastung des Bodensees mit Phosphor- und Stickstoffverbindungen, organisch gebundenem Kohlenstoff und Borat im Abflussjahr 1985/86. Bericht Nr. 40, 52 pp.

Jensen, J. P., P. Kristensen, E. Jeppesen, 1991. Relationships between nitrogen loading and in-lake nitrogen concentrations in shallow Danish lakes. Verh. int. Verein. Limnol.: $201-204$.

Kaplan, W., 1983. Nitrification. In: J. E. Carpenter, D. G. Capone (eds), Nitrogen in the marine environment, Academic Press, New York, 139-190.

Kelly, C. A., J. W. M. Rudd, R. H. Hesslein, D. W. Schindler, P. J. Dillon, C. T. Driscoll, S. A. Gherini and R. E. Hecky, 1987. Prediction of biological acid neutralization in acid-sensitivelakes. Biogeochemistry 3:129-140.

Knowles, R., D. R. Lean, Y. K. Chan, 1981. Nitrous oxide concentrations in lakes: variations with depth and time. Limnol. Oceanogr. 26:855-865.

Knowles, R., 1982. Denitrification. Microbiol. Rev. 46:43-70.

Krummenacher, T., 1976. Die Nährstoffbilanz des Alpnachersees. Ph. D. dissertation ETH Nr. 5689, $135 \mathrm{pp}$.

Kunz, W., 1977. Die Belastung und Entlastung des Zürichsees hinsichtlich Phosphor- und Stickstoffverbindungen. Vierteljahresschrift Naturforsch. Ges. Zürich 122:249-337.

Lemon, E., D. Lemon, 1981. Nitrous oxide in freshwater of the Great Lakes Basin. Limnol. Oceanogr. 26:62-75.

Leu, D., R. Biedermann, J. Dettweiler, J. Hoigné, F. X. Stadelmann, 1986. Bericht über Nitrate im Trinkwasser - Standortbestimmung 1985. Mittl. Gebiete Lebensm. Hyg. 77:227-315.

Lohri, F., 1977. Untersuchung der Zuflüsse des Baldeggersees 1975/76: Bericht z. Hd. des Schweiz. Bundes für Naturschutz und des Kant. Amtes für Gewässerschutz Luzern, 46 pp.

Losher, A. J., K. R. Kelts, 1989. Organic sulphur fixation in freshwater lake sediments and the implication for C/S ratios. Terra Nova 1:253-261.

Müller, G., J. Dominik, A. Mangini, 1979. Eutrophication changes sedimentation in part of Lake Constance. Naturwissenschaften 66:261-262.

Müller, R., 1990. Stickstoff-Toxizität für Fische und herzuleitende Grenzwerte. EAWAG News 30 (1990):33-36. 
OECD (Organisation for Economic Cooperation and Development) 1980: OECD Eutrophication programme - Regional project - Alphine lakes. Swiss Federal Board for Environmental Protection, Bern.

Pleisch, P., 1970. Die Herkunft eutrophierender Stoffe beim Pfäffiker- und Greifensee. Vierteljahresschrift Naturforsch. Ges Zürich 115:127-229.

Ryther, J. H., W. M. Dunstan, 1971. Nitrogen, phosphorus and eutrophication in the coastal marine environment. Science 171:1008-1013.

Schlatter, J., D. Imboden, W. Stumm, 1988. Sanierung des Baldeggersees: Auswertung der Zuflussuntersuchungen; Messperiode Mai 1985 bis April 1987. EAWAG Auftrag Nr. 4693, $32 \mathrm{pp}$.

Schuler, C., E. Wieland, P. H. Santschi, M. Sturm, A. Lueck, S. Bollhalder, J. Beer, G. Bonani, H. J. Hofmann, M. Suter, W. Wölfli, 1991. A multi tracer study of radionuclides in Lake Zürich, Switzerland: I. Comparison of atmospheric and sedimentary fluxes of ${ }^{10 / 7} \mathrm{Be},{ }^{210} \mathrm{~Pb},{ }^{210} \mathrm{Po}$ and ${ }^{137}$ Cs. J. Geophys. Res. 96:17051-17065.

Schuurkes, J. A., R. Mosello, 1988. The role of ammonium inputs in freshwater acidification. Schweiz. Z. Hydrol. 50:71-86.

Seitzinger, S. P., 1988. Denitrification in freshwater and coastal marine ecosystems: ecological and geochemical significance. Limnol. Oceanogr. 33/4 part 2:702-724.

Stadelmann, P., 1971. Stickstoffkreislauf und Primärproduktion im mesotrophen Vierwaldstättersee (Horwer Bucht) und im eutrophen Rotsee, mit besonderer Berücksichtigung des Nitrats als limitierender Faktor. Schweiz. Z. Hydrol. 33:1-65.

Stadelmann, P., 1988. Zustand des Sempachersees vor und nach der Inbetriebnahme der see-internen Massnahmen: Künstlicher Sauerstoffeintrag und Zwangszirkulation. Wasser - Energie - Luft $80: 81-96$.

Stadelmann, P., T. Joller, D. Imboden, 1984. Die Auswirkung von internen Massnahmen im Baldeggersee: Zwangszirkulation und Sauerstoffbegasung des Hypolimnions. Verh. Internat. Verein. Limnol. 22:1052-1065.

Thomas, E., 1955. Stoffhaushalt und Sedimentation im oligotrophen Ägerisee und im eutrophen Pfäffikersee und Greifensee. Mem. Ist. Ital. Idrobiol. Suppl. 8:357-465.

Thomas, E., 1956. Stoffhaushalt und Sedimentation im Türlersee. Schweiz. Ver. Gas- und Wasserfm. 12:1-11.

Vollenweider, R. A., 1968. The scientific basis of lake and stream eutrophication. Technical Report DAS/CSI/68. The Organization for Economic Cooperation and Development (OECD), Paris, 1968.

Vollenweider, R. A., 1975. Input-output models. Schweiz. Z. Hydrol. 37:29-68.

Wan, G. J., P. H. Santschi, M. Sturm, K. Farrenkothen, A. Lück, E. Werth, Ch. Schuler., 1987. Natural $\left({ }^{210} \mathrm{~Pb},{ }^{7} \mathrm{Be}\right)$ and fallout $\left({ }^{137} \mathrm{Cs},{ }^{239,240} \mathrm{Pu},{ }^{90} \mathrm{Sr}\right)$ radionuclides as geochemical tracers of sedimentation in Greifensee, Switzerland. Chem Geol. 63:181-196.

Wieland, E., P. H. Santschi, P. Höhener, M. Sturm, 1993. Chernobyl ${ }^{137} \mathrm{Cs}$ and natural ${ }^{210} \mathrm{~Pb}$ in Lake Sempach, Switzerland: Removal processes and remobilization from sediments. Geochim. Cosmochim. Acta, in press.

Yoh, M., H. Terai, Y. Saijo, 1988. Nitrous oxide in freshwater lakes. Arch Hydrobiol. 113:273-294.

Zimmermann, C., 1991. Sanierung des Hallwilersees. Zuflussuntersuchung zur Nährstoffbelastung 1988/90. Baudepartement Kanton Aargau-Abteilung Umweltschutz; Amt für Umweltschutz des Kantons Luzern; Gemeindeverband Baldegger- und Hallwilersee, Nov. 1991.

Zobrist, J., H. Bührer, J. Davis, 1990. Zeitliche Entwicklung des Stickstoffs in den schweizerischen Gewässern. EAWAG News 30 (1990):14-18.

Received 13 August 1992;

revised manuscript accepted 25 January 1993. 